\title{
Komunikasi Pemasaran PT. Bach Multi Global dalam Membangun Kepercayaan Konsumen
}

\author{
Thiara Ivankha Pratama, Suherman Kusniadji \\ thiaraivankha97@gmail.com, kusniadji@gmail.com \\ Fakultas Ilmu Komunikasi Universitas Tarumanagara
}

\begin{abstract}
This study discusses the marketing communication methods used by PT. Bach Multi Global in building Consumer trust. The purpose of this study is that the writer will analyze the marketing communication activities of PT. Bach Multi Global in building Consumer trust. This study uses the theory of marketing communication and integrated marketing communication. The methodology of this study uses qualitative research methods with the type of descriptive research and literature study at PT. Bach Multi Global. The results of this study the authors know that PT. Bach Multi Global only uses the personal selling, direct marketing, and word of mouth marketing marketing communication methods because PT. Bach Multi Global is a company that sells industrial products, and does not sell retail. Consumer Trust can be seen from the forms of cooperation between PT. Bach Multi Global with large companies in Indonesia, and various Consumers from certain circles. Consumers of PT. Bach Multi Global also recommends generator sets sold by PT. Bach Multi Global to other Consumers without being affected by offers from other companies.
\end{abstract}

Keywords: Marketing Communication, Consumers Trust, PT. Bach Multi Global

\begin{abstract}
Abstrak
Penelitian ini membahas tentang metode-metode komunikasi pemasaran yang digunakan oleh PT. Bach Multi Global dalam membangun kepercayaan Konsumen. Tujuan dari penelitian ini adalah penulis akan menganalisis kegiatan komunikasi pemasaran PT. Bach Multi Global dalam membangun kepercayaan Konsumen. Penelitian ini menggunakan teori komunikasi pemasaran dan komunikasi pemasaran terpadu. Metodologi penelitian ini menggunakan metode penelitian kualitatif dengan jenis penelitian deskriptif dan studi kepustakaan di PT. Bach Multi Global. Hasil dari penelitian ini penulis mengetahui bahwa PT. Bach Multi Global hanya menggunakan metode komunikasi pemasaran personal selling, direct marketing, dan word of mouth marketing karena PT. Bach Multi Global adalah perusahaan yang menjual produk industri, dan tidak menjual secara retail. Kepercayaan Konsumen dapat dilihat dari bentuk-bentuk kerja sama PT. Bach Multi Global dengan perusahaan-perusahaan besar di Indonesia, dan berbagai Konsumen dari kalangan tertentu. Konsumen PT. Bach Multi Global juga ikut merekomendasikan produk genset yang dijual oleh PT. Bach Multi Global kepada Konsumen lain tanpa terpengaruh penawaran dari perusahaan lain.
\end{abstract}

Kata Kunci: komunikasi pemasaran, kepercayaan Konsumen, PT. Bach Multi Global.

\section{Pendahuluan}

Genset atau generator set adalah sebuah perangkat yang bisa menghasilkan listrik. Perangkat ini disebut generator set karena perangkat ini merupakan satu set peralatan gabungan dari 2 perangkat yang berbeda, yaitu mesin dengan 
generator/alternator. Pada genset, mesin berfungsi sebagai alat pemutar sedangkan generator/alternator berfungsi sebagai perangkat pembangkit listrik.

Genset pertama kali ditemukan oleh Michael Faraday dan Rudolph Diesel. Mereka menemukan 2 elektromagnetik dan induksi listrik di tahun yang berbeda. Faraday menemukan sebuah induksi elektromagnetik sekitar tahun 1831 dan kemudain penemuan ini berkembang menjadi generator moderen. Lalu ia mengeluarkan hak paten atas mesin yang ia temukan pada tahun 1892 .

Karena penemuan ini sangat bermanfaat bagi kehidupan manusia, maka mesin penghasil listrik ini mulai dikembangkan dan diproduksi secara massal. Saat ini genset mudah ditemui dimana-mana karena sudah banyak tersedia di pasaran. Mesin penghasil listrik ini umumnya digunakan di rumah sakit, pabrik, hotel, supermarket dan mal. Namun saat ini tidak jarang rumah-rumah penduduk yang mulai menggunakan genset untuk mengantisipasi jika terjadi pemadaman listrik. (https://jualmesingenset.wordpress.com/sejarah-generator-set-genset/)

Namun, dengan banyaknya perusahaan yang bergerak di bidang ini, mereka pun berlomba-lomba untuk dapat memimpin pasar genset di Indonesia. Agar produknya dapat mendapat kepercayaan Konsumen, maka diperlukan kegiatan komunikasi pemasaran yang tepat. Salah satu perusahaan yang akan penulis teliti adalah PT. Bach Multi Global. Bergerak dalam bidang genset berskala kecil dan besar, mulai dari 4000 Watt sampai 2.400.000 Watt . Beberapa perusahaan pesaing PT. Bach Multi Global adalah PT. Hartekprima Listrindo, PT. Aneka Jaya Langgeng Sentosa, dan PT. Taneko. Ketiga pesaing tersebut mempunyai kesamaan produk/barang yang dijual, yang membedakan hanya persaingan pada harga dan support supplier saja.

Komunikasi pemasaran yang digunakan oleh PT. Bach Multi Global adalah direct marketing, personal selling dan words of mouth marketing. Berdasarkan latar belakang tersebut, penulis tertarik melakukan penelitian pada PT. Bach Multi Global karena perusahaan ini mampu menjadi perusahaan yang berskala besar tanpa melakukan penjualan online tetapi hanya mengandalkan pemasaran off-line. Dimana pada era penjualan secara online, PT. Bach Multi Global tetap setia di jalur off-line, merupakan tantangan besar yang dilakukan oleh PT. Bach Multi Global dalam berkompetisi bisnis dengan para pesaingnya meskipun tidak menggunakan pemasaran secara online. Maka penulis tertarik untuk melakukan penelitian yang berjudul "Kegiatan Komunikasi Pemasaran PT. Bach Multi Global dalam Membangun Kepercayaan Konsumen"

\section{Metode Penelitian}

\section{a. Komunikasi}

Menurut Hermawan (2012:4), komunikasi adalah proses menyampaikan informasi, pesan, ide, gagasan dari satu pihak lain sehingga terjadi saling mempengaruhi di antara keduanya. komunikasi merupakan proses penyampaian pesan dari satu orang ke orang lain dengan maksud bertukar pesan agar pesan dapat tersampaikan dengan baik maka setiap komunikasi selalu melibatkan dua orang atau lebih yaitu pengirim pesan (sender) dan penerima pesan (reciever). Dalam setiap komunikasi pasti diperlukan timbal balik agar proses penyampaian pesan dapat diterima dan mencapai tujuan dari komunikasi itu sendiri. 
Thiara Ivankha Pratama, Suherman Kusniadji: Komunikasi Pemasaran PT. Bach Multi Global dalam Membangun Kepercayaan Konsumen

\section{b. Komunikasi Pemasaran}

Komunikasi pemasaran merupakan gambaran komunikasi yang bertujuan untuk memperdalam strategi pemasaran, untuk meraih tingkatan pasar yang lebih luas. Dengan adanya komunikasi pemasaran, sang penjual akan lebih mudah untuk menejelaskan produk yang dijual kepada konsumen demi menambah keuntungan baik pribadik maupun perusahaan. Contoh kegiatan pemasaran yang berhubungan dengan bentuk aktivitas komunikasi adalah iklan, tenaga penjualan, papan nama toko, kemasan produk, dan alat-alat komunikasi lainnya.

c. Personal Selling

Menurut Peter dan Deonnelly (2004) yang dikutip oleh Priansa (2017:220) menyatakan bahwa personal selling adalah kegiatan ini dilakukan oleh salah satu strategi bauran promosi. Personal selling adalah metode komunikasi pemasaran yang dilakukan secara langsung antara penjual dan pembeli melalui tatap muka.

Berdasarkan berbagai pengertian yang dijelaskan tersebut, personal selling adalah salah satu strategi dalam bauran komunikasi pemasaran yang dilakukan melalui komunikasi dua arah secara langsung. Personal selling merupakan aktivitas komunikasi antara sales person dan Konsumen potensial yang melibatkan pikiran dan emosi dari sales person ataupun Konsumen itu sendiri.

d. Direct Marketing

Direct Marketing merupakan sistem pemasaran yang menyebabkan perusahaan dan pemasar mampu melakukan komunikasi secara langsung dengan Konsumennya dalam rangka menghasilkan respons atau transaksi yang juga bersifat langsung. Respons yang dihasilkan dari direct marketing tersebut, antara lain adalah inquiry, pembelian, atau dukungan terhadap Konsumen dalam memutuskan sebuah tindakan. Keberhasilan pemasar melalui direct marketing sangat ditentukan oleh kemampuan perusahaan atau pemasar untuk memilih target pasar serta mendesain kampanye direct marketing-nya.

Tujuan direct marketing adalah melakukan kontak langsung dengan konsumen melalui media yang sering digunakan (misalnya computer, telepon, surat, dan fax). Ada beberapa manfaat direct marketing dari konsumen dan produsen, bagi konsumen adalah dapat melaksanakan transaksi belanja dirumah dengan praktis.belanja dirumah pun akan merasa menyenangkan, nyaman dan bebas dari pertengkaran. Dengan adanya cara ini konsumen dapat menghemat banyak waktu. Konsumen juga dapat memesan barang untuk mereka sendiri maupun untuk orang lain.

e. Word of Mouth Marketing

Priansa (2017:338) menyatakan bahwa salah satu strategi pemasaran yang efektif untuk mengurangi biaya promosi dan alur distribusi perusahaan. Word of mouth dapat mempengaruhi orang lain, image, pikiran, serta keputusan mereka.

Dari definisi di atas dapat disimpulkan bahwa word of mouth communication merupakan suatu bentuk percakapan mengenai suatu produk, antara satu orang dengan orang lainnya, di dalamnya terdapat pesan yang disampaikan yang terkadang tidak disadari oleh pemberi informasi dan penerima informasi.

\section{Hasil Temuan dan Diskusi}

a. Personal Selling

Cron dan Decarlo (2010) yang dikutip oleh Priansa (2017:220) menyatakan bahwa personal selling adalah komunikasi langsung antara sales representation dan prospect dalam sebuah proses agar terjadi transaksi, pemenuhan kebutuhan 
Konsumen, perkembangan penjualan, dan hubungan yang menguntungkan, sependapat dengan pengertian personal selling menurut Tjiptono (2008) yang dikutip oleh Priansa (2017:220) menyatakan bahwa personal selling merupakan komunikasi langsung (tatap muka) antara penjual dan calon Konsumen untuk memperkenalkan suattu produk sehingga mereka kemudian akan mencoba membelinya. Oleh karena itu, sistem kerjanya lebih fleksibel jika dibandingkan dengan media lainnya. Dan dikuatkan oleh teori dari Kotler dan Amstrong (2012) yang dikutip oleh Priansa (2017:220) menyatakan bahwa personal selling merupakan penyajian secara tatap muka yang dilakukan oleh wiraniaga dalam rangka penjualan dan membina hubungan dengan Konsumen.Berdasarkan berbagai pengertian dan penjelasan tentang personal selling oleh key informan maupun informan yang penulis wawancarai dan dikaitkan dengan teori dari para ahli, personal selling adalah aktivitas komunikasi antara sales marketing yang potensial yang melibatkan pikiran dan emosi dari sales person ataupun Konsumen itu sendiri.

Menurut penulis dari hasil wawancara yang sudah dilakukan, metode komunikasi pemasaran personal selling merupakan komunikasi pemasaran yang efektif karena dengan adanya metode ini, sang penjual dan pembeli dapat bertukar pikiran untuk saling mengerti apa yang dapat dilakukan oleh penjual untuk memuaskan Konsumennya, serta pembeli dapat langsung menemukan jawaban yang diperlukan dari penjual.

\section{b. Word of Mouth}

Mahendrayasa et al (2004) yang dikutip oleh Priansa (2017:338) yaitu word of mouth terjadi melalui dua sumber yang menciptakannya, yaitu reference group (grup referensi) dan opinion leader. Word of mouth terbentuk dalam suatu grup karena pada kenyataannya Konsumen lebih percaya orang lain daripada iklan yang diluncurkan oleh perusahaan. Sependapat dengan Andreas (2012) yang dikutip oleh Priansa (2017:338) yang menyatakan bahwa word of mouth pada dasarnya adalah pesan tentang produk atau jasa suatu perusahaan, ataupun tentang perusahaan itu sendiri, dalam bentuk komentar tentang kinerja produk, keramahan, kejujuran, kecepatan pelayanan, dan hal lainnya yang dirasakan dan dialami oleh sesorang yang disampaikan kepada orang lain.

Word of mouth bagi PT. Bach Multi Global merupakan sebuah kegiatan pemasaran dalam memberikan informasi suatu produk/jasa dari satu Konsumen kepada Konsumen lainnya untuk membicarakan, mempromosikan, dan mau menjual suatu merek kepada orang lain.

Menurut penulis dari hasil wawancara yang sudah dilakukan maka, word of mouth merupakan metode komunikasi pemasaran yang sangat bermanfaat, karena dengan adanya word of mouth marketing ini penjual tidak perlu lagi menjelaskan secara detail tentang produk yang dipasarkan karena sudah mendapatkan penjelasan berupa feedback dari teman, kerabat, maupun saudara dari pembeli dan yang pasti seorang pembeli akan lebih percaya kepada satu perusahaan karena sudah mendapat rekomendasi dari orang lain.

Kotler dan Amastrong (2012) yang dikutip oleh Priansa (2017:108) menyatakan bahwa pemasaran langsung berkenaan dengan penggunaan telepon, surat, faks, $e$ mail, internet, dan alat-alat lainnya dalam rangka mengkomunikasikan secara langsung kepentingan perusahaan kepada Konsumen secara lebih spesifik. Pernyataan tersebut juga sependapat dengan Peter Bennett (2002) yang dikutip oleh Priansa (2017:108) direct marketing adalah semua kegiatan yang dilakukan agar dapat mengefisienkan adanya pertukaran barang dan jasa dengan cara menggunakan 
satu atau lebih media yang bertujuan untuk menghasilkan tanggapan secara langsung dari konsumen, baik melalui telepon, surat maupun tatap muka.

Menurut penulis berdasarkan berbagai pernyataan yang dinyatakan oleh para key informan dan informan yang dikaitkan oleh penulis dengan pengertian-pengertian dari para ahli, direct marketing adalah salah satu metode pemasaran yang digunakan oleh PT. Bach Multi Global melalui media interaktif sehingga perusahaan dan Konsumen dapat berinteraksi secara langsung dan hasilnya dapat langsung diukur pula.

\section{Simpulan}

Menurut analisis data dan hasil penelitian yang dilakukan oleh penulis mengenai Kegiatan Komunikasi Pemasaran PT. Bach Multi Global dalam Membangun kepercayaan Konsumen maka penulis dapat mengambil kesimpulan :

1. Dalam melakukan kegiatan pemasaran PT. Bach Multi Global tidak dapat melakukan seluruh bauran pemasaran karena PT. Bach Multi Global bukan perusahaan yang menjual secara retail sehingga hanya dapat menggunakan beberapa metode komunikasi pemasaran yaitu word of mouh marketing, personal selling, dan direct marketing sebagai media untuk menyampaikan informasi mengenai produk dan jasa yang dijual oleh perusahaan.

2. Penggunaan personal selling sangat bermanfaat bagi Konsumen karena dengan adanya personal selling tersebut seorang sales dapat secara langsung menjelaskan kelebihan maupun kekurangan produk yang dijual, dan seorang Konsumen akan dapat memberikan masukkan tentang barang atau produk yang diinginkan sehingga dapat terjadi transaksi.

3. Penggunaan e-mail bagi sebagian Konsumen tidak terlalu bermanfaat karena zaman ini sudah canggih, direct marketing juga dapat dilakukan melalui WhatsApp ataupun aplikasi lainnya yang sedang in saat ini. Tetapi bagi sebagian Konsumen penggunaan e-mail untuk direct marketing sangat bermanfaat walaupun terkesan sangat tradisional, karena penggunaan $e$-mail masih terbilang efektif daripada penggunaan aplikasi lainnya, ini merupakan media yang sangat bermanfaat untuk menyampaikan informasi tentang produk dengan cepat tanpa harus bertatap muka secara langsung.

4. Penggunaan metode komunikasi pemasaran word of mouth marketing sangat bermanfaat bagi perusahaan, karena dengan adanya metode ini suatu perusahaan tidak lagi harus menjelaskan secara detail tentang perusahaan tersebut. Jika kepuasan Konsumen telah terpenuhi maka word of mouth marketing akan muncul secara langsung, dan calon Konsumen akan lebih percaya kepada perusahaan karena mendapat rekomendasi dari orang sekitar.

5. Penggunaan pemasaran secara online hanya dilakukan oleh PT. Bach Multi Global untuk mempromosikan perusahaan secara singkat, lalu selanjutnya sales akan follow-up seorang calon Konsumen dengan menggunakan metode komunikasi pemasaran direct marketing dan personal selling.

\section{Ucapan Terima Kasih}

Penulis mengucapkan terimakasih kepada 4 orang Key Informan dan Informan yang telah bersedia untuk menyempatkan waktu untuk wawancara. Penulis juga mengucapkan terimakasih kepada orang tua, teman-teman, dan dosen pembimbing 
yang telah memberikan dukungan dan saran kepada penulis agar penulis dapat menyelesaikan laporan skripsi dengan baik.

\section{Daftar Pustaka}

Bungin, B. (2011). Metodologi Penelitian Kualitatif. Jakarta: Kencana.

Cron, W. L., \& Decarlo, T. E. (2010). Sales Management 10th Edition. Texas: Hoboken, N.J : Wiley.

Hermawan, A. (2012). Komunikasi Pemasaran. Jakarta: Erlangga.

Jefkins, F. (2004). Komunikasi Pemasaran. Jakarta: Erlangga.

Kennedy, J. E., \& Soemanagara, R. D. (2006). Marketing Communication: Taktik \& Strategi. Jakarta: Bhuana Ilmu Komputer.

Kotler, P., \& Amstrong, G. (2014). Prinsip-prinsip Manajemen Edisi 14, Jilid 1. Jakarta: Erlangga.

Kotler, P., \& Keller, K. L. (2012). Manajemen Pemasaran Edisi 2012. Jakarta: Erlangga.

Machfoedz, M. (2010). Komunikasi Pemasaran Modern. Yogyakarta: Cakra Ilmu.

Moleong, L. J. (2011). Metodologi Penelitian Kualitatif. Bandung: PT. Remaja Rosdakarya.

Moleong, L. J. (2017). Metodologi Penelitian Kualitatif. Bandung: Rosdakarya.

Mulyana, D. (2005). Ilmu Komunikasi Suatu Pengantar. Bandung: Remaja Rosdakarya.

Prianssa, D. J. (2017). Komunikasi Pemasaran Terpadu. Bandung: CV Pustaka Setia.

Solomon, M. (2007). Behaviour : Buying, Having, Being. Harlow: Pearson Education Limited.

Sugiyono. (2012). Memahami Penelitian Kualitatif. Bandung: Alfa Beta.

Sugiyono. (2013). Metode Penelitian Pendekatan Kualitatif, Kuanitatif dan R\&D. Bandung: Alfa Beta.

Sugiyono. (2017). Metode Penelitian Kuantitatif Kualitatif dan R\&D. Bandung: Alfabeta.

Sumardy, M. S., \& Malone, M. (2011). The Power of Word of Mouth Markting . Jakarta: Gramedia Pustaka Utama.

Supardi, M. (2006). Metodologi Penelitian . Mataram: Yayasan Cerdas Press.

Widjojo, H. (2017). Sari-Sari Pemasaran dan Aplikasinya di Dunia Bisnis. Jakarta: Prasetiya Mulya Publishing.

Yin, R. K. (2011). Studi Kasus : Desain dan Metode. Jakarta: Rajagrafindo Persada. 